\title{
Interpersonal interaction within the violin teaching studio: the influence of interpersonal dynamics on outcomes for teachers.
}

Word count inclusive of references and tables: 8035

\section{Introduction}

In instrumental tuition, teacher-pupil relationships and teacher-parent communication have been found to play key roles in determining the level of musical expertise which an individual is able to attain (Sloboda and Howe, 1991; Manturzewska, 1990; Sosniak, 1990). However, although a growing body of evidence demonstrates the considerable responsibilities of the teacher at each stage of musical development the existing body of research is largely pupil-centred; there is little evidence concerning the impact of teacher-pupil-parent relationships on the outcomes for teachers themselves.

Systems theory, characterized by concepts of reciprocity and holism (Tubbs, 1984), would suggest that an understanding of teachers' beliefs, attitudes and experience within learning partnerships forms an inextricable strand of our knowledge about teaching and learning outcomes for all participants. Accordingly, the aim of this paper is to explore whether or not teachers' beliefs and attitudes relating to interpersonal interaction with pupils and parents influences the outcomes experienced by teachers themselves. Specifically, this paper addresses the research question of whether instrumental teachers' experience of the interpersonal dynamics of control and responsiveness, manifest within teacher-pupil and teacher-parent dyads, accounts for variability in their levels of professional satisfaction, teacher efficacy and involvement with pupils and parents. 
Andrea Creech

\section{Background}

\section{Teacher-pupil relationships}

In common with other teaching situations the development of motivation in one-toone music tuition requires teachers to be relatively uncritical, encouraging and enthusiastic during the initial stages of learning (Hallam, 1998). Indeed, regardless of the pupil's level of expertise, relationships with teachers have been found to have a significant impact on outcomes for the learners. Studies of distinguished young instrumentalists in the USA (Sosniak, 1990) and Poland (Manturzewska, 1990) have both described in detail the importance of the teacher at three stages in the development of musical expertise. Memories of early teachers in the first stage were predominated by images of warm and enthusiastic people who made the lessons fun and were quick to provide rewards, generating interest and enthusiasm. In contrast, during the second stage knowledgeable criticism from teachers and other experts became valued and the relationship between teacher and pupil changed to one of respect. In the third phase of development, characterized by a master-apprentice relationship, the nature of the teaching learning relationship changed yet again. Here, although pupils began to develop autonomous learning strategies, an important component in optimal development was the master-student relationship. The master exerted considerable power, critiquing students' performances and also initiating them into the world of musical values, introducing them into professional circles and facilitating their transition into professional musicians. Where an appropriate masterstudent relationship was not developed this was found to have a potential negative influence on the musical development of the individual (Manturzewska, 1990; Sosniak, 1990). 


\section{Andrea Creech}

Teacher-pupil relationships in the context of instrumental lessons, have been found to be heavily influenced by the teacher's own life histories, and in particular past relationships with their own teachers (Morgan, 1998). Student personality characteristics also determine the way that teacher behaviours are perceived (Schmidt, 1989; Schmidt and Stephans, 1991). Furthermore, there may be tacit interpersonal dynamics operating between teachers and pupils in lessons, whereby defence mechanisms may be adopted by teachers to ward off unpleasant memories relating to their own experience as a learner (Gustafson, 1986). Inevitably, some teacher-pupil matches will be better than others but as professionals teachers arguably have the responsibility for setting minimum standards of interpersonal behaviour which they apply consistently whatever the circumstances (Hallam, 1998).

\section{Teacher-parent relationships}

Teacher-parent relationships have also been found to play a key role in determining successful learning outcomes (Creech, 2001). Music education research, to date, has provided much compelling evidence that teacher-parent communication, particularly during the early years of instrumental learning, is indeed linked to musical achievement (Brokaw, 1982; Davidson et al., 1996; Doan, 1973; Sosniak, 1985). Years of related educational research, theory and wisdom sustain this view (Baker, 1997). Thus, teachers are compelled within our current educational climate to forge good relationships with pupils and their parents.

\section{Control and responsiveness}

An overview of the literature related to the question of how best to sustain appropriate and effective teacher-parent-pupil interaction in the context of instrumental learning 


\section{Andrea Creech}

includes research concerned with a) concepts of effective learning and teaching, b) concepts of effective parenting and c) dimensions of interpersonal relationships. Repeatedly, the findings of research concerned with these three distinct areas place emphasis on the importance of the interpersonal dimensions of responsiveness and control. Van Tartwijk (1998) presents a model of effective teaching based on the concepts of control and responsiveness. This is similar to conceptions of a successful authoritative parenting style encompassing both parental responsiveness and demandingness (Baumrind, 1989; Maccoby and Martin, 1983). Steinberg et al. (1989) provided depth to the notion of authoritative parenting, claiming that authoritative parents, whose parenting style was found to contribute to academic aspirations and achievement amongst their children, treated their children warmly and democratically, yet with a degree of behavioural control. Dimensions of these teaching and parenting models are captured in Birtchnell's interpersonal theory (Birtchnell, 1993). Representing the control construct as an upperness-lowerness axis and the responsiveness construct as a closeness-distance axis, Birtchnell makes the point that healthy interpersonal interactions may occur at any point on this matrix. While upperness provides the opportunity to impart knowledge and exert influence, lowerness provides a space where individuals may receive care and attention and benefit from other's knowledge. While closeness represents the possibility for communion, distance provides opportunities for development of agency (ibid).

Existing research findings in the realm of instrumental learning provide a valuable insight into developmental issues such as parent supervision of practice (Brokaw, 1982; Davidson et al., 1996) or teacher strategies and use of lesson time (Duke, 1999; Gholson, 1998; Hallam, 2006; Kostka, 1984; Siebenaler, 1997), and have 


\section{Andrea Creech}

demonstrated cause and effect relationships between such factors and pupil achievement. Hallam (2006) emphasizes the importance of the teacher's role in making music tuition 'fun and enjoyable', and identifies a wide range of non-musical benefits perceived by instrumental teachers (ibid: 113). However, previous research in the domain of musical instrument learning has neither specifically examined the interpersonal dimensions of responsiveness and control within learning partnerships, nor explored how these dimensions might influence teaching and learning outcomes for individuals other than the pupils. Thus, this research differs from previous studies in the same domain in its explicit focus on the implications for teachers of the interpersonal dimensions of control and responsiveness.

\section{Systems theory}

Systems theory provides a framework for understanding the complexity of parentteacher-pupil interaction, providing scope for control and responsiveness to be interpreted as characteristics of a communicative system. Circular communication processes develop which not only consist of behaviour but which determine behaviour as well. 'When individuals communicate, their behaviours will mutually influence each other' (Van Tartwijk et al., 1998: 608). From such a stance, an individual's particular interpersonal style may be seen as both causing and resulting from a web of complex interaction.

Tubbs (1984) defines a small group as 'a collection of individuals who influence one another, derive some satisfaction from maintaining membership in the group, interact for some purpose, assume specialized roles, are dependent on one another, and communicate face to face' (ibid: 8). The parent-teacher-pupil microsystem, in the 


\section{Andrea Creech}

specific context of musical instrument learning, matches all the above criteria. Systems theorists place an emphasis on understanding the constituent parts of a system in relation to the dynamic properties of the whole unit (Pianta and Walsh, 1996); the findings reported here are specifically concerned with teachers, addressing the question of whether teachers' beliefs about their relationships with both pupils and parents account for variability in their own professional satisfaction, teacher efficacy and involvement with pupils and parents.

\section{Methods}

\section{Development of the Survey}

The views of teachers were elicited via the 'Survey of Teacher Attitudes', developed for this investigation from existing research instruments that variously purport to measure a) children's satisfaction with instrumental lessons (Rife et al., 2001), b) parent involvement in children's instrumental learning (Doan, 1973) and c) interpersonal qualities of teachers (Wubbels et al., 1993).

\section{Modification of existing research instruments}

For the research reported here, attitude statements from the existing measures were modified so as to apply specifically to violin teachers. For example, where the original statement eliciting pupils' views about their teachers' interaction styles was 'he seems uncertain' (Wubbels et al., 1993: 20), the revised version for violin teachers (control scale) was 'I am sometimes uncertain as to the best way to proceed with a pupil'. In a similar vein, where the original statement was 'he is patient' (ibid), the modified statement for this study (teacher responsiveness scale) was 'I am patient with pupils, when they find it difficult to master something on the violin' (see Creech, 2006 for a full list of original and revised statements). Respondents were asked to 


\section{Andrea Creech}

respond to each statement on the new scales by indicating their agreement, using a five point Likert scale ranging from 1 (strongly disagree) to 5 (strongly agree) and with a 'neutral' mid-point of 3.

The new survey was piloted with a group of 30 teachers and scrutinized by two music education professionals. Items that did not bear significant correlations with the overall scale to which they belonged were discarded, as were those items where the experts did not agree the item corresponded with the scale and where respondents indicated they did not understand. The final control and responsiveness scales together comprised 24 items, reduced from the original 64 items measuring teacher interaction style (Wubbels et al., 1993).

The aim of the survey was to establish a measurement of how the interpersonal dimensions of control and responsiveness influenced outcomes for teachers that had been defined in earlier research (Creech, 2001). Hence in addition to the groups of statements relating to scales for interpersonal mechanisms (Table 3: control and Table 4: responsiveness, below) the survey included scales for outcomes that for teachers were defined as involvement, teacher efficacy and professional satisfaction (See Tables 7 and 9, below). The teacher outcomes scales (professional satisfaction, teacher efficacy and involvement) comprised statements drawn from the three original sources, again with wording modified to apply specifically to the violin teacher respondents. An original pool of 55 possible items for these scales was reduced, through the process of scrutiny noted above, to a total of 18 items used in this study. 
Andrea Creech

\section{Scales for control, responsiveness and teacher efficacy}

Wubbels et al's (1993) Questionnaire on Teacher Interaction (QTI) provided a model of interpersonal behaviour developed from Leary (1957), who conceptualized all interpersonal behaviour around the two axes of responsiveness and control. The original QTI, which included a scale for teacher efficacy, was developed and tested for reliability by Dutch and Australian researchers (Brekelmans, 1989, Creton and Wubbels, 1984; Fisher et al., 1992; Wubbels et al., 1987). Alpha coefficients on each scale (segment of the model) were consistently greater than .70, demonstrating internal consistency. Adapted from the QTI, the survey of teachers developed for this research included five-point Likert scales measuring teacher efficacy as well as the interpersonal mechanisms of control and responsiveness as they were operationalized within teacher-pupil and teacher-parent dyads.

\section{Professional satisfaction scale}

Basing their research on the premise that children's feelings of satisfaction are vital to learning because they provide the motivation necessary to persevere, Rife et al. (2001) examined components related to satisfaction with private music lessons from a child's perspective. To this end they developed a measure of music lesson satisfaction, with the intention that the findings should contribute to improvement in private instrumental instruction. Internal consistency of the Music Lesson Satisfaction Scale (MLSS) was high (Cronbach's Alpha $=.94)$. The MLSS included open ended questions regarding likes and dislikes about lessons, teachers, musical styles and repertoire, practice, and family influence. Results demonstrated that enjoyment of music chosen by the teacher, increased playing time in lessons and practising were related to children's music lesson satisfaction. Items from the MLSS were modified 


\section{Andrea Creech}

for the research reported here in order to provide a measurement of teachers' professional satisfaction.

\section{Involvement scale}

Relationships between parental involvement in music and performance ability of violinists were explored by Doan (1973), who developed a Parent Involvement Questionnaire (PIQ) and established its validity by a process of scrutiny by experts. Significant correlations $(\mathrm{p}<.0001)$ were found between performance ability and parent involvement components which included the number of years a student played the violin, the number of years a student had had private lessons, and whether parents attended student concerts and listened to student practice. Adding depth to his quantitative findings, Doan conducted case studies of families of superior violin students and concluded that the family activities considered by his research participants as providing the most important support for the child's musical development were provision of private lessons, attendance at all private lessons, frequent assistance with practice, parental insistence on a regular practice routine and attendance at the child's concerts. While Doan's conclusions suggested that musical achievement was influenced by a great deal of parental involvement in the learning process, he did not explore the implicit involvement of the teacher, nor did he examine any outcomes apart from pupils' musical achievement. The PIQ was adapted in this research to allow for the possibility of an exploration of the implications of involvement, for teachers.

\section{Sample}


Andrea Creech

Two hundred and sixty-three violin teachers were surveyed, representing a response rate of $31 \%$. The teachers were all members at least one of the professional organisations including the British branch of the European String Teacher's Association (ESTA), the Incorporated Society of Musicians (ISM), and the British Suzuki Institute (BSI) and postal return questionnaires were distributed as inserts with the official newsletters of these professional organizations. Thirty-nine (15\%) of teachers were male, while $220(84 \%)$ were female (4 did not state gender). Respondents from around Britain were aged from 20 to 75 and their years of teaching experience ranged from 1 to over 30 (Table 1).

\section{TABLE 1 HERE}

The teachers, often indicating that they taught in more than one type of teaching environment, taught in maintained schools (46\%), independent schools (41\%), private studios (74\%), specialist music schools (14\%), music colleges and university music departments $(13 \%)$. Their pupils included beginners (92\% of teachers), grade 1-3 (92\% of teachers), grade $4-5$ (89\% of teachers), grade 6-8 (82\% of teachers) and post grade 8 (46\% of teachers). Ninety-three percent of teachers had pupils aged 5-10, while $94 \%$ taught pupils aged $11-16,65 \%$ taught pupils aged $17-25$ and $52 \%$ taught adults aged over 25 . The teachers had pupil class sizes ranging from under 14 to over 60. Several teaching methods and approaches were represented (Table 2).

\section{TABLE 2 HERE}


Andrea Creech

\section{Results}

\section{Teacher control and responsiveness scales}

The teacher control and responsiveness scales demonstrated moderate internal consistency, with significant correlations $(\mathrm{p}<.0001)$ found between the mean score for each of the scale items and the mean score for the corresponding overall scale. The mean inter-item correlation for the control scale was 0.16 , while for responsiveness it was 0.17 (slightly below the optimal range of $.2-.4$ recommended by Briggs and Cheek (1986).

\section{Control}

Table 3 demonstrates that the greatest amount of agreement was found in responses to statements indicating that teachers had high expectations of pupils, explained these expectations clearly to parents and always offered critical appraisals of pupil performance, during lessons. In each of these instances the responses clustered around the high end of the scale. There was also relatively strong agreement that parents would value the lessons and pupils would achieve their potential if they followed the teacher's advice, with scores clustered towards the high end of the scale in the latter case, but more evenly distributed in the former. Despite indicating that pupils would do best to follow the teacher's advice, there was also moderate agreement that teachers were sometimes uncertain about how to proceed with pupils. Responses suggested that teachers considered themselves to be more patient and tolerant with pupils than with parents. Low mean scores were found in relation to whether teachers agreed that they were not tolerant when pupils made mistakes and whether they had little patience with pupils who did not meet their expectations. Conversely, there was higher agreement in relation to whether teachers found it difficult to be patient with 


\section{Andrea Creech}

parents who did not make a serious commitment to the violin lessons or did not follow their advice on matters related to the violin, as well as in relation to whether teachers expected parents to give high priority to violin study. Despite these fairly high expectations of parents, there was moderate agreement that teachers were sometimes uncertain as to how best to communicate with parents.

\section{TABLE 3 HERE}

\section{Responsiveness}

High mean scores (skewed towards the top end of the scale) in relation to statements concerned with teacher-pupil responsiveness suggested that the majority of teacher respondents rewarded pupil achievement with praise, welcomed the views of pupils, considered themselves to be patient with pupils and aware when pupils did not understand direction, were happy to communicate with pupils outside of lessons, and were prepared to compromise when pupils had different goals to their own. Responses in relation to the teacher-parent relationship were more variable; whilst there were relatively high mean scores suggesting that teachers were interested in parents' views welcomed their feedback on matters relating to violin study there was a lower mean score for the statement that assessed whether teachers considered themselves to be tolerant when parents disagreed with them over these same matters. Futhermore, in contrast to the statement where teachers had strongly agreed that they knew when pupils had not understood their directions, a low mean score was found in relation to whether teachers considered themselves to be aware when parents did not understand their directions (Table 4).

\section{TABLE 4 HERE}


Andrea Creech

\section{Underlying interpersonal dimensions}

A correlation matrix of all of the variables on each scale was examined in order to confirm that the majority of significance values were smaller than 0.05 and that none of the correlation coefficients were greater than 0.9 (Field, 2000). Furthermore, the Kaiser-Meyer-Olkin measure of sampling adequacy was checked, and where this produced a reasonably high value it was deemed that principal component analysis should yield distinct and reliable components (ibid: 455). The teacher control and responsiveness scales met these criteria for a valid principal component analysis, and in accordance with Kaiser (1960) principal component analysis was carried out in order to ascertain whether there were underlying dimensions contributing to these constructs.. Component loadings greater than 0.364 for a sample size greater than 200 were considered significant (Stevens, 1992). Eignevalues greater than 1 were retained and in order to ensure that variables were loaded maximally on to only one component Varimax rotation was selected.

\section{Underlying dimensions of control}

The KMO measure of sampling adequacy showed a value of 0.702 , indicating that principal component analysis was a suitable statistical procedure for these data. The correlation matrix of responsiveness variables confirmed the majority of significance values were smaller than 0.5 and none of the correlation coefficients were greater than 0.9 , indicating that the control scale met the criteria for principal component analysis (Field, 2000).

Despite Leary's assertion that all interpersonal behaviour may be represented in terms of control or responsiveness, a principal component analysis of the control construct, 


\section{Andrea Creech}

as measured by the teacher control scale, revealed four components, interpreted as 1) leadership 2) commitment, 3) impatience and 4) confidence (Table 5).

\section{TABLE 5 HERE}

Component one (leadership) related to high expectations of pupils and parents, high teacher efficacy in relation to the subject matter, as well as the belief that parents and pupils should give high priority to the violin and follow the teacher's advice. There were some cross-loadings, with items concerned with the belief that pupils and parents would benefit most if they follow the teacher's advice as well as the expectation that parents should give high priority to violin study also being associated with component two, interpreted as commitment.

Statements loading on to component two (commitment) related to the teacher's belief that both pupils and parents should be seriously committed to the subject matter, allowing it high priority in their lives and taking the teacher's advice seriously. Again, there were some cross-loadings, with items concerned with lack of tolerance when parents fell short of teacher's expectations also associated with component three, which was interpreted as impatience.

Component three (impatience) was concerned with levels of tolerance of pupil mistakes, patience with pupils who did not meet expectations, and patience with parents who neither followed the teacher's advice nor made a serious commitment to the violin. Table 5 (above) demonstrates that component three variables were all framed negatively and all bore a significant positive correlation with the component. Thus this component of the control construct was interpreted as impatience rather than patience. 
Andrea Creech

Finally, statements that loaded highly on to component four were associated with teacher efficacy and confidence (or lack of it) in one's ability to explain expectations clearly as well as to communicate effectively.

\section{Underlying dimensions of responsiveness}

The KMO measure of sampling adequacy showed a value of 0.744 , indicating that principal component analysis was again a suitable statistical procedure for these data. This assumption was supported by the correlation matrix of responsiveness variables that confirmed the majority of significance values were smaller than 0.5 and none of the correlation coefficients were greater than 0.9 , indicating that the responsiveness scale met the criteria for principal component analysis.

Four responsiveness components were revealed and interpreted as 1) sensitivity to pupils, 2) receptiveness to new ideas, 3) interest in the views of others and 4) communication skills (Table 6).

\section{TABLE 6 HERE}

Component one (sensitivity to pupils) were concerned with teacher empathy and compassion for pupils. Rewarding achievement with praise, patience when pupils found something difficult, awareness of when pupils did not understand the teacher, and personal interest in the pupil were reflected in these statements.

Component two (receptiveness to new ideas) was comprised of variables that were concerned with willingness to communicate and compromise over differences. These statements suggested the qualities of approachability and accessibility over exchange of ideas or feelings. 
A genuine interest in the views of both pupils and parents was reflected in the variables that loaded on to component three (interest in the views of others). This component differed from component two (receptiveness to new ideas) in that the statements reflected a more proactive attitude towards exchange of ideas. For example, while a component two variable stated 'I am prepared to compromise', a component three statement more explicitly said 'I welcome the views of pupils'.

Component four was concerned with communication skills, and labelled as such. Variables that loaded on to this component were concerned with the teacher's willingness to explain concepts again to pupils, and with the teacher's awareness of whether or not parents had understood their directions.

\section{The influence of control and responsiveness components on outcomes for teachers}

This study was primarily concerned with an exploration of how interpersonal dynamics influence teaching and learning experience. For teachers, involvement, efficacy and professional satisfaction were identified as possible outcomes (Creech, 2001). Internal reliability on each of the scales for these three outcomes (see Table 7 , below) was found to be moderate - strong, with mean inter-item correlations ranging between .22 and .75 (Pallant, 2007), and significant correlations found between every individual variable and the overall scale to which it belonged.

Standard multiple regressions, which predict outcomes from more than one independent variable, were carried out for each outcome scale, using component scores for the four control components (Table 5) and four responsiveness components 
Andrea Creech

(Table 6) as predictors. Because variables comprising confidence and communication skills were framed negatively, negative Beta coefficients (providing information about the relationship between each predictor and the outcome) for these components imply a positive relationship.

\section{Involvement}

Responses on the teacher-pupil involvement scale (Table 7) demonstrated that teacher respondents perceived their responsibilities to extend well beyond the boundaries of the teaching studio. There was strong agreement that the teachers considered it their duty to provide pupils with performance opportunities and with information about instruments and materials. There was more ambiguity amongst the responses in relation to whether or not teachers initiated communication with their pupils outside of lesson times, although the mean score was still relatively high.

\section{TABLE 7 HERE}

Keen willingness to engage in teacher-parent involvement was manifest in the responses, as reported in table 7 . Strong agreement was found in relation to whether teachers welcomed parents to sit in on lessons, welcomed communication from parents outside of scheduled lesson time and were happy to initiate this communication themselves. However, some ambivalence towards parent involvement was implicit in the responses; the greatest amount of variation was concerned with the belief that the teacher was more effective when the parent was not there. 


\section{Andrea Creech}

The responses suggested that majority of teachers expected parents to assist with home practice and agreed that parents should make their children practice. This, taken together with the strong agreement amongst teachers that they expected parents to attend pupil concerts, suggested that teachers depended on parents to support and facilitate their children's instrumental studies.

Standard multiple regression, entering the component scores for teacher control and responsiveness components (computed by SPSS using the regression method) as regressors, revealed that variability in involvement with pupils and parents was explained most by sensitivity to pupils $(B=.601, \mathrm{p}<.0001)$, followed by commitment $(B=.254, \mathrm{p}=.002)$ and teacher impatience $(B=.206, \mathrm{p}=.031)($ Table 8). The other predictors were non-significant (Table 8). The multiple correlation coefficient for the model was $\mathrm{R}=.694$ and all of the predictors together accounted for $48 \%$ of variability in teacher involvement $\left(\mathrm{F}_{8,98}=11.380, \mathrm{p}<.0001\right)$.

\section{TABLE 8 HERE}

\section{Teacher efficacy}

Teacher responses on the teacher efficacy scale seemed to contradict the finding that many teachers agreed or strongly agreed that they sometimes were uncertain as to how to proceed with a pupil, noted above. Table 9 indicates that the large majority of respondents believed they were effective teachers, believed they provided their pupils with a strong sense of direction on the violin, believed they always explained their expectations clearly to pupils, and saw themselves as maintaining and encouraging a positive attitude towards violin study. 
Andrea Creech

TABLE 9 HERE

Variability in teacher efficacy was explained to the greatest extent by teacher confidence $(B=-.347, \mathrm{p}<.0001)$, leadership $(B=.324, \mathrm{p}<.0001)$ and, to a lesser extent, by commitment $(B=.297, \mathrm{p}<.0001)$ and sensitivity to pupils $(B=.184, \mathrm{p}=$ .045). The other predictors were non-significant (Table 10). Together this model produced a multiple correlation with the teacher efficacy scale of $R=.695$, and accounted for $48 \%$ of variability on the teacher efficacy scale $\left(\mathrm{F}_{8,104}=12.158, \mathrm{p}<\right.$ $.0001)$.

\section{TABLE 10 HERE}

\section{Professional satisfaction}

A large majority of respondents agreed or strongly agreed that teaching the violin was a rewarding job and that they were enthusiastic about teaching (Table 9, above).

Teacher sensitivity to pupils was found to make the strongest unique contribution to explaining variability in professional satisfaction $(B=.398, \mathrm{p}<.0001)$. Similarly, the responsiveness component of interest in the views of others made a strong contribution to explaining this outcome $(B=-.292, \mathrm{p}=.001)$. To a lesser extent, variability on the professional satisfaction scale was explained by the control components of leadership $(B=-.261, \mathrm{p}=.004)$ and confidence $(B=-.247, \mathrm{p}=.005)$. The other components were non-significant (Table 11). The model, including all of the predictors together, produced a multiple correlation with the professional satisfaction scale of $R=.665$, and accounted for $44 \%$ of variability on the scale $\left(\mathrm{F}_{8}\right.$, $105=10.398, \mathrm{p}<.0001)$. 
Andrea Creech

\section{TABLE 11 here}

\section{Discussion}

This paper explores whether underlying dimensions of control and responsiveness, as measured in the 'Survey of Teacher Attitudes', influenced teacher professional satisfaction, self efficacy and involvement.

The survey results suggested an association between the interpersonal quality of responsiveness and the outcomes of teacher efficacy and professional satisfaction. In particular, teacher 'sensitivity to pupils' made a significant contribution to variability in all of the outcomes, while, in addition, 'interest in the views of others' was a further responsiveness component that in this case had a negative effect for the outcome of professional satisfaction. One interpretation of this counter-intuitive finding is that while the quality of the teacher-pupil relationship (reflected in 'sensitivity to pupils') had a significant positive effect on outcomes for teachers, a great deal of parental input and feedback (reflected in 'interest in the views of others') potentially had a negative effect on teacher satisfaction.

Teacher efficacy was found to be particularly influenced by facets of teacher control, including leadership, commitment and confidence. It has been shown that by a process of collective efficacy enhancement, self efficacious teachers may empower parents with the confidence to help their children learn, and instill in their pupils self efficacious beliefs which support persistence with learning and enhance student attitudes towards the teacher and the subject matter'(Creech and Hallam, 2003: 35). The findings presented here suggest that the circular, cyclical nature of efficacy may 


\section{Andrea Creech}

thus be greatly influenced by qualities of teacher control together with sensitivity to pupils.

All of the control and responsiveness components accounted for variability in least some of the outcomes. Teacher leadership, commitment and confidence (control components) each bore significant correlations with two of the three specified teacher outcomes, while the component that bore the largest coefficient for any one of the outcomes was sensitivity to pupils (a responsiveness component) and At the heart of this finding is the dilemma facing many teachers whereby in order to be effective they must be responsive leaders, providing authoritative direction but also compelled to respond to the individual pupil needs and parental wishes or circumstances. A tension between responsiveness (teacher sensitivity) and control (leadership, commitment and confidence) is captured in this illustration of how the components derived from both scales consistently influenced outcomes for teachers.

While it was evident that teachers did in many instances perceive the need to be controlling with regard to setting learning objectives there was a sense too that teachers were reticent about positioning themselves in this way, preferring to convey a self-image characterized by responsiveness. Hence a challenge for violin teachers was to strike a balance between fulfilling the teacher role of imparting knowledge and skills whilst maintaining a responsive, co-operative persona. The balance was made more precarious by the fact that violin teachers operate within a domain where the achievement of expertise only comes with much discipline and extensive application, yet where enjoyment is perhaps a key to the motivation to persevere. 
It has been suggested by family system analysts that the healthiest families are those characterised by relationships where there is variation in types of interaction, as opposed to individuals being locked into one type of exchange (Becvar and Becvar, 1996). Applied to the teacher-pupil-parent relationship, this model of a healthy system offers a solution to the control vs. responsiveness dilemma, allowing scope for, and embracing of, both types of interaction. Framing this approach to interpersonal interaction in terms of Birtchnell's relating theory, whereby neither control not responsiveness is privileged, provides opportunities for teachers to develop a range of interpersonal skills representing all points on the controlresponsiveness matrix, and to develop knowledge of when these skills may be used to greatest effect in their relationships with both pupils and parents. Furthermore, the results presented here are reminiscent of models of effective parenting that encompass concepts of both responsiveness and demandingness (Maccoby et al., 1983) or democracy and behavioural control (Steinberg et al., 1992) that have been found to be associated with enhanced outcomes for pupils and parents alike. This would suggest that these parenting models have much to offer our understanding of teacher-pupilparent dynamics and how interpersonal interaction may be associated with teaching and learning outcomes.

The research presented here was exploratory in nature and limited in several respects. First of all, we do not know about the experience of those teachers who did not respond to the survey; a larger response rate could alter the results considerably. Secondly, the scales for teacher control and responsiveness yielded relatively low measures of reliability (inter-item mean correlations of slightly below 0.2 ). Future 
Andrea Creech

research is needed that would refine these scales and, indeed, investigate these complex interpersonal processes employing qualitative as well as quantitative methodologies. Third, the sample was not balanced for gender; this in itself points to future research that investigates gender issues in instrumental teaching, as well as demanding further research that specifically investigates the relationship of teacher, pupil and parent gender with interpersonal dimensions. Fourth, this research was restricted to teachers of the violin, pointing to future research that investigates whether interpersonal relating styles amongst instrumental teachers, pupils and parents is instrument-specific. Finally, as systems theory would suggest, research is needed that will investigate whether teachers' beliefs relating to interpersonal interaction with pupils and parents impacts upon outcomes for other members of the learning partnership, and vice-versa. 


\section{References}

Baker, A. (1997) 'Parent Involvement in Children's Education: A Critical Assessment of the Knowledge Base', Annual Meeting of the American Education Research Association. New York: Eric Document Reproduction Service.

Baumrind, D. (1989) 'Rearing Competent Children', in W. Damon (ed.), Child Development Today and Tomorrow, pp.349-378. London: Jossey-Bass.

Becvar, D. \& Becvar, R. (1996) Family Therapy: A Systemic Integration. Boston, USA: Allyn and Bacon.

Birtchnell, J. (1993) How Humans Relate: A New Interpersonal Theory. UK: Psychology Press.

Brekelmans, M. (1989) Interpersoonlijk gedrag von docenten in de klas (Interpersonal Teacher Behaviour in the Classroom. Utrecht, The Netherlands: WCC.

Briggs, S. \& Cheek, J. (1986) 'The Role of Factor Analysis in the Development and Evaluation of Personality Scales', Journal of Personality 54 (1): 106-148.

Brokaw, J.P. (1982) The Extent To Which Parental Supervision And Other Selected Factors Are Related To Achievement Of Musical And TechnicalPhysical Characteristics By Beginning Instrumental Music Students. Music, University of Michigan, Michigan, USA: Unpublished PHD.

Creech, A. (2001) Play for me: An Exploration into Motivations, Issues and Outcomes Related to Parental Involvement in their Children's Violin Study. Music, University of Sheffield, Sheffield: Unpublished MA.

Creech, A. (2006) Dynamics, Harmony and Discord: A Systems Analysis of Teacher-Pupil-Parent Interaction in Instrumental Learning. Institute of Education, University of London: Unpublished PhD.

Creech, A. and Hallam, S. (2003) 'Parent-Teacher-Pupil Interactions in Instrumental Music Tuition: a Literature Review', British Journal of Music Education 20(1), 29-44.

Creton, H. and Wubbels, T. (1984) Discipline Problems With Beginning Teachers. Utrecht, The Netherlands: WCC.

Davidson, J., Howe, M., Moore, D. and Sloboda, J. (1996) 'The Role of Parental Influences in the Development of Musical Performance', British Journal of Developmental Psychology 14(4): 399-412. 
Doan, G. (1973) An Investigation of the Relationships Between Parental Involvement and the Performance Ability of Violin Students. Music, Ohio State University, Ohio, USA: Unpublished PHD.

Duke, R.A. (1999) 'Measures of Instructional Effectiveness in Music

Research', Bulletin of the Council for Research in Music Education 143: 1-42.

Field, A. (2000) Discovering Statistics Using SPSS. London: Sage Publications.

Fisher, D.L., Fraser, B.J. \& Wubbels, T. (1992) Teacher Communication Style and School Environment. Paper presented at ECER Conference, Enshede, The Netherlands.

Gholson, S.A. (1998) 'Proximal Positioning: A Strategy of Practice in Violin Pedagogy', Journal of Research in Music Education 46(4): 535-545.

Gustafson, R. (1986) 'Effects of Interpersonal Dynamics in the StudentTeacher Dyads on Diagnostic and Remedial Content of Four Private Violin Lessons', Psychology of Music 14(2): 130-139.

Hallam, S. (1998) Instrumental Teaching. Oxford: Heinemann.

Hallam, S. (2006) Music Psychology in Education. London: Institute of Education, University of London.

Kaiser, H.F. (1960) 'The Application of Electronic Computers to Factor Analysis', Educational and Psychological Measurement 20: 141-151.

Kostka, M. (1984) 'An Investigation of Reinforcements, Time Use, and Student Attentiveness in Piano Lessons', Journal of Research in Music Education 32(2), 113-122.

Leary, T. (1957) Interpersonal Diagnosis of Personality: A Functional Theory and Methodology for Personality Evaluation. New York: Ronald Press Company.

Maccoby, E. \& Martin, J. (1983) 'Socialization in the Context of the Family: Parent-Child Interaction', in E.M. Hetherington and P.H. Mussen (eds.), Handbook of Child Psychology, Vol. 4. Socialization, Personality and Social Development, pp.1-101. New York: Wiley.

Manturzewska, M. (1990) 'A Biographical Study of the Life-Span Development of Professional Musicians', Psychology of Music 18(2): 112-139.

Morgan, C. (1998) Instrumental Music Teaching and Learning: a life history approach. Education, University of Exeter, Exeter: Unpublished PhD.

Pallant, J. (2007) SPSS Survival Manual. Maidenhead, England: Open University Press. 
Pianta, R. \& Walsh, D. (1996) High-Risk Children in Schools. New York: Routledge.

Rife, N.A., Shenk, Z.M., Lauby, J.L. and Lapidus, L.B. (2001) 'Children's Satisfaction with Private Music Lessons', Journal of Research in Music Education 49(1): 21-32.

Schmidt, C.P. (1989) 'Individual Differences in Perception of Applied Music Teaching Feedback', Psychology of Music 17(2): 110-112.

Schmidt, C.P. \& Stephans, R. (1991) 'Locus of Control and Field Dependence as Factors in Students Evaluations of Applied Music Instruction', Perceptual and Motor Skills 73(1): 131-136.

Siebenaler, D.J. (1997) 'Analysis of Teacher-Student Interaction in the Piano Lessons of Adults and Children', Journal of Research in Music Education 45(1): 6-20.

Sloboda, J. and Howe, M. (1991) ' Biographical Precursors of Musical Excellence: An Interview Study', Psychology of Music 19(1): 3-21.

Sosniak, L.A. (1985) 'Learning to be a Concert Pianist', in B.S. Bloom (ed.) Developing Talent in Young People, pp.19-67. New York: Ballantine.

Sosniak, L.A. (1990) 'The Tortoise, The Hare, and the Development of Talent', in M. Howe (ed.), Encouraging the Development of Exceptional Skills and Talents pp.149-164. Leicester: The British Psychological Society.

Steinberg, L., Elmen, J. and Mounts, N. (1989) 'Authoritative parenting, Psychosocial Maturity and Academic Success among Adolescents', Child Development 60(6): 1424-1436.

Steinberg, L., Lamborn, S.D. and Darling, N. (1992) 'Impact of Parenting Practices on Adolescent Achievement: Authoritative Parenting, School Involvement, and Encouragement to Succeed', Child Development 63: 12661281.

Stevens, J.P. (1992) Applied Multivariate Statistics for the Social Sciences (2nd edition). Hillsdale N.J: Erlbaum.

Tubbs, S.L. (1984) A Systems Approach to Small Group Interaction. New York: Random House.

Van Tartwijk, J., Brekelmans, M. and Wubbels, T. (1998) 'Students' Perceptions of Teacher Interpersonal Style: The Front of the Classroom as the Teacher's Stage', Teaching and Teacher Education 14(6): 607-617. 
Andrea Creech

Wubbels, T., Creton, H., Brekelmans, M. and Hooymayers, H. (1987) 'The perception of the teacher-student relationship', Tijdschrift voor

Onderwijsresearch 12: 3-16.

Wubbels, T., Creton, H. and Levy, J. (1993) The Model for Interpersonal

Teacher Behaviour', in T. Wubbels and J. Levy (eds.) Do You Know What You Look Like? Interpersonal Relationships in Education, pp.13-28. London: Falmer Press. 
Andrea Creech

\begin{tabular}{|c|c|c|c|c|c|c|c|}
\hline \multirow{2}{*}{\multicolumn{2}{|c|}{$\begin{array}{l}\text { teacher's gender and number of } \\
\text { pupils }\end{array}$}} & \multicolumn{5}{|c|}{ years of teaching experience } & \multirow[t]{2}{*}{ Total } \\
\hline & & \multirow[t]{2}{*}{$\begin{array}{c}1-4 \\
\text { years }\end{array}$} & \multirow[t]{2}{*}{$\begin{array}{c}5-9 \\
\text { years }\end{array}$} & \multirow[t]{2}{*}{$\begin{array}{l}10-14 \\
\text { years }\end{array}$} & \multirow[t]{2}{*}{$\begin{array}{l}15-20 \\
\text { years }\end{array}$} & \multirow[t]{2}{*}{$\begin{array}{c}\text { over } 20 \\
\text { years }\end{array}$} & \\
\hline Unknov & emographics & & & & & & 4 \\
\hline \multirow[t]{6}{*}{ male } & 1-14 pupils & & $\begin{array}{c}0 \\
.0 \%\end{array}$ & $\begin{array}{c}2 \\
22.2 \%\end{array}$ & $\begin{array}{c}2 \\
28.6 \%\end{array}$ & $\begin{array}{c}4 \\
20.0 \%\end{array}$ & $\begin{array}{c}8 \\
20.5 \%\end{array}$ \\
\hline & 15-29 pupils & & $\begin{array}{c}2 \\
66.7 \%\end{array}$ & $\begin{array}{c}2 \\
22.2 \%\end{array}$ & $\begin{array}{c}1 \\
14.3 \%\end{array}$ & $\begin{array}{c}5 \\
25.0 \%\end{array}$ & $\begin{array}{c}10 \\
25.6 \%\end{array}$ \\
\hline & 30-44 pupils & & $\begin{array}{c}0 \\
.0 \%\end{array}$ & $\begin{array}{c}2 \\
22.2 \%\end{array}$ & $\begin{array}{c}1 \\
14.3 \%\end{array}$ & $\begin{array}{c}2 \\
10.0 \%\end{array}$ & $\begin{array}{c}5 \\
12.8 \%\end{array}$ \\
\hline & 45-60 pupils & & $\begin{array}{c}1 \\
33.3 \%\end{array}$ & $\begin{array}{c}0 \\
.0 \%\end{array}$ & $\begin{array}{c}2 \\
28.6 \%\end{array}$ & $\begin{array}{c}2 \\
10.0 \%\end{array}$ & $\begin{array}{c}5 \\
12.8 \%\end{array}$ \\
\hline & over 60 pupils & & $\begin{array}{c}0 \\
.0 \%\end{array}$ & $\begin{array}{c}3 \\
33.3 \%\end{array}$ & $\begin{array}{c}1 \\
14.3 \%\end{array}$ & $\begin{array}{c}7 \\
35.0 \%\end{array}$ & $\begin{array}{c}11 \\
28.2 \%\end{array}$ \\
\hline & Total $(100 \%)$ & & 3 & 9 & 7 & 20 & 39 \\
\hline \multirow[t]{6}{*}{ female } & 1-14 pupils & $\begin{array}{c}1 \\
7.7 \%\end{array}$ & $\begin{array}{c}9 \\
33.3 \%\end{array}$ & $\begin{array}{c}3 \\
10.7 \%\end{array}$ & $\begin{array}{c}7 \\
15.6 \%\end{array}$ & $\begin{array}{c}15 \\
14.0 \%\end{array}$ & $\begin{array}{c}35 \\
15.9 \%\end{array}$ \\
\hline & 15-29 pupils & $\begin{array}{c}5 \\
38.5 \%\end{array}$ & $\begin{array}{c}5 \\
18.5 \%\end{array}$ & $\begin{array}{c}11 \\
39.3 \%\end{array}$ & $\begin{array}{c}13 \\
28.9 \%\end{array}$ & $\begin{array}{c}26 \\
24.3 \%\end{array}$ & $\begin{array}{c}60 \\
27.3 \%\end{array}$ \\
\hline & 30-44 pupils & $\begin{array}{c}0 \\
.0 \%\end{array}$ & $\begin{array}{c}3 \\
11.1 \%\end{array}$ & $\begin{array}{c}2 \\
7.1 \%\end{array}$ & $\begin{array}{c}7 \\
15.6 \%\end{array}$ & $\begin{array}{c}22 \\
20.6 \%\end{array}$ & $\begin{array}{c}34 \\
15.5 \%\end{array}$ \\
\hline & 45-60 pupils & $\begin{array}{c}1 \\
7.7 \%\end{array}$ & $\begin{array}{c}3 \\
11.1 \%\end{array}$ & $\begin{array}{c}6 \\
21.4 \%\end{array}$ & $\begin{array}{c}4 \\
8.9 \%\end{array}$ & $\begin{array}{c}19 \\
17.8 \%\end{array}$ & $\begin{array}{c}33 \\
15.0 \%\end{array}$ \\
\hline & over 60 pupils & $\begin{array}{c}6 \\
46.2 \%\end{array}$ & $\begin{array}{c}7 \\
25.9 \%\end{array}$ & $\begin{array}{c}6 \\
21.4 \%\end{array}$ & $\begin{array}{c}14 \\
31.1 \%\end{array}$ & $\begin{array}{c}25 \\
23.4 \%\end{array}$ & $\begin{array}{c}58 \\
26.4 \%\end{array}$ \\
\hline & Total $(100 \%)$ & 13 & 27 & 28 & 45 & 107 & 220 \\
\hline
\end{tabular}

Table 1: number of pupils, years of teaching experience and teacher's gender 
Andrea Creech

\begin{tabular}{|c|c|c|}
\hline Method & Number of teachers & Percent \\
\hline no specific method & 177 & 67.3 \\
\hline 'my own' & 9 & 3.4 \\
\hline Suzuki & 49 & 18.6 \\
\hline Rolland & 4 & 1.5 \\
\hline Nelson & 5 & 1.9 \\
\hline Eta Cohen & 4 & 1.5 \\
\hline Colourstrings & 4 & 4.2 \\
\hline Other & 11 & 100.0 \\
\hline Total & 263 & \\
\hline
\end{tabular}

Table 2: teaching method 


\section{Andrea Creech}

\begin{tabular}{|c|c|c|c|}
\hline & Mean & $\begin{array}{c}\text { Std. } \\
\text { Deviation }\end{array}$ & Skewness \\
\hline I have high expectations of my pupils. & 4.19 & .87 & -.91 \\
\hline $\begin{array}{l}\text { I always offer critical appraisals of my pupil's } \\
\text { performance, during violin lessons. }\end{array}$ & 4.07 & .87 & -.72 \\
\hline I explain my expectations clearly to parents. & 3.99 & .79 & -.43 \\
\hline $\begin{array}{l}\text { I believe parents will value their children's violin lessons, } \\
\text { if they follow my advice on matters related to their } \\
\text { children's violin study. }\end{array}$ & 3.84 & .77 & .18 \\
\hline $\begin{array}{l}\text { I believe my pupils will achieve their potential on the } \\
\text { violin, if they do what I say. }\end{array}$ & 3.62 & .98 & -.48 \\
\hline $\begin{array}{l}\text { I am sometimes uncertain as to the best way to proceed } \\
\text { with a pupil. }\end{array}$ & 3.46 & 1.02 & -.64 \\
\hline $\begin{array}{l}\text { I find it difficult to be patient with parents who do not } \\
\text { follow my advice on matters related to their child's violin } \\
\text { study. }\end{array}$ & 3.41 & .98 & -.23 \\
\hline $\begin{array}{l}\text { I find it difficult to be patient with parents who do not } \\
\text { make a serious commitment to their child's violin study. }\end{array}$ & 3.38 & 1.05 & -.31 \\
\hline $\begin{array}{l}\text { I expect parents to give high priority in their lives to their } \\
\text { children's violin study. }\end{array}$ & 3.30 & .95 & -.50 \\
\hline $\begin{array}{l}\text { I am sometimes uncertain as to the best way to } \\
\text { communicate with parents. }\end{array}$ & 2.76 & 1.06 & -.17 \\
\hline $\begin{array}{l}\text { I am not tolerant when my pupils make musical mistakes } \\
\text { in pieces they know. }\end{array}$ & 2.14 & .98 & .86 \\
\hline $\begin{array}{l}\text { I have little patience with pupils who do not meet my } \\
\text { expectations on the violin. }\end{array}$ & 1.87 & .82 & .87 \\
\hline
\end{tabular}

Table 3: Teacher control scale responses: mean scores, standard deviation and skewness 


\section{Andrea Creech}

\begin{tabular}{|c|c|c|c|}
\hline & Mean & $\begin{array}{c}\text { Std. } \\
\text { Deviation }\end{array}$ & Skewness \\
\hline I reward my pupils' musical achievements with praise. & 4.78 & .43 & -1.67 \\
\hline $\begin{array}{l}\text { I welcome the views of pupils, on matters relating to violin } \\
\text { study. }\end{array}$ & 4.55 & .60 & -1.08 \\
\hline $\begin{array}{l}\text { I am patient with pupils, when they find it difficult to master } \\
\text { something on the violin. }\end{array}$ & 4.49 & .66 & -1.26 \\
\hline $\begin{array}{l}\text { I am interested in knowing what my pupils hope to achieve, } \\
\text { through violin study. }\end{array}$ & 4.48 & .69 & -1.18 \\
\hline $\begin{array}{l}\text { I am happy to communicate with pupils outside of scheduled } \\
\text { lesson time. }\end{array}$ & 4.28 & .68 & -.63 \\
\hline I know when pupils do not understand my directions. & 4.13 & .65 & $\begin{array}{l}-39 \\
\end{array}$ \\
\hline $\begin{array}{l}\text { I am prepared to compromise, when pupils have different } \\
\text { goals from my own. }\end{array}$ & 4.07 & .79 & -.78 \\
\hline $\begin{array}{l}\text { I am interested in knowing why parents want their child to } \\
\text { learn the violin. }\end{array}$ & 4.00 & .74 & -.45 \\
\hline $\begin{array}{l}\text { I welcome the views of parents on matters relating to violin } \\
\text { study. }\end{array}$ & 3.89 & .76 & -.82 \\
\hline $\begin{array}{l}\text { I am tolerant when parents disagree with me over matters } \\
\text { relating to violin study. }\end{array}$ & 3.06 & .92 & -.24 \\
\hline I never know if parents understand my directions. & 2.41 & .82 & .65 \\
\hline $\begin{array}{l}\text { I don't like explaining musical concepts again, to the same } \\
\text { pupil. }\end{array}$ & 1.83 & .96 & 1.31 \\
\hline
\end{tabular}

Table 4: Responsiveness scale responses: mean scores, standard deviation and skewness 


\section{Andrea Creech}

\begin{tabular}{|c|c|c|c|c|}
\hline & \multicolumn{4}{|c|}{ Control component } \\
\hline & $\begin{array}{c}1 \\
\text { Leadership* }\end{array}$ & $\begin{array}{c}2 \\
\text { Commitment }^{*}\end{array}$ & $\begin{array}{c}3 \\
\text { Impatience* }\end{array}$ & $\begin{array}{c}4 \\
\text { Confidence* }^{*}\end{array}$ \\
\hline $\begin{array}{l}\text { I have high expectations of my } \\
\text { pupils. }\end{array}$ & .729 & & & \\
\hline $\begin{array}{l}\text { I always offer critical } \\
\text { appraisals of my pupil's } \\
\text { performance, during violin } \\
\text { lessons. }\end{array}$ & .633 & & & \\
\hline $\begin{array}{l}\text { I explain my expectations } \\
\text { clearly to parents. }\end{array}$ & .554 & & & \\
\hline $\begin{array}{l}\text { I believe parents will value } \\
\text { their children's violin lessons, } \\
\text { if they follow my advice on } \\
\text { matters related to their } \\
\text { children's violin study. }\end{array}$ & .529 & .468 & & \\
\hline $\begin{array}{l}\text { I expect parents to give high } \\
\text { priority in their lives to their } \\
\text { children's violin study. }\end{array}$ & .527 & .368 & & \\
\hline $\begin{array}{l}\text { I believe my pupils will } \\
\text { achieve their potential on the } \\
\text { violin, if they do what I say. }\end{array}$ & .389 & .524 & & \\
\hline $\begin{array}{l}\text { I find it difficult to be patient } \\
\text { with parents who do not follow } \\
\text { my advice on matters related } \\
\text { to their child's violin study. }\end{array}$ & & .803 & .316 & \\
\hline $\begin{array}{l}\text { I find it difficult to be patient } \\
\text { with parents who do not make } \\
\text { a serious commitment to their } \\
\text { child's violin study. }\end{array}$ & & .700 & .449 & \\
\hline $\begin{array}{l}\text { I am not tolerant when my } \\
\text { pupils make musical mistakes } \\
\text { in pieces they know. }\end{array}$ & & & .742 & \\
\hline $\begin{array}{l}\text { I have little patience with } \\
\text { pupils who do not meet my } \\
\text { expectations on the violin. }\end{array}$ & & & .709 & \\
\hline $\begin{array}{l}\text { I am sometimes uncertain as } \\
\text { to the best way to proceed } \\
\text { with a pupil. }\end{array}$ & & & & .847 \\
\hline $\begin{array}{l}\text { I am sometimes uncertain as } \\
\text { to the best way to } \\
\text { communicate with parents. }\end{array}$ & & & & .798 \\
\hline
\end{tabular}

Table 5: Control components

* Component loadings less than $\mathbf{3 6 4}$ for a sample size greater than 200 are suppressed (Stevens, 1992) 


\section{Andrea Creech}

\begin{tabular}{|l|c|c|c|c|}
\hline \multirow{2}{*}{} & \multicolumn{3}{|c|}{ Responsiveness component } \\
\cline { 2 - 5 } & $\begin{array}{c}1 \\
\text { sensitivity } \\
\text { to pupils* }\end{array}$ & $\begin{array}{c}\text { 2 } \\
\text { receptiveness to } \\
\text { new ideas* }\end{array}$ & $\begin{array}{c}\text { 3 } \\
\text { interest in } \\
\text { views of } \\
\text { others* }\end{array}$ & $\begin{array}{c}\text { communication } \\
\text { skills* }\end{array}$ \\
\hline $\begin{array}{l}\text { I reward my pupils' musical } \\
\text { achievements with praise. }\end{array}$ & .721 & & & \\
\hline $\begin{array}{l}\text { I am patient with pupils, } \\
\text { when they find it difficult to } \\
\text { master something on the } \\
\text { violin. }\end{array}$ & .704 & & & \\
\hline $\begin{array}{l}\text { I know when pupils do not } \\
\text { understand my directions. }\end{array}$ & .597 & & & \\
\hline $\begin{array}{l}\text { I am interested in knowing } \\
\text { what my pupils hope to } \\
\text { achieve, through violin } \\
\text { study. }\end{array}$ & .582 & & & \\
\hline $\begin{array}{l}\text { I welcome the views of } \\
\text { pupils, on matters relating } \\
\text { to violin study. }\end{array}$ & .553 & & & \\
\hline $\begin{array}{l}\text { I am prepared to } \\
\text { compromise, when pupils } \\
\text { have different goals from } \\
\text { my own. }\end{array}$ & & & & \\
\hline $\begin{array}{l}\text { I am happy to communicate } \\
\text { with pupils outside of } \\
\text { scheduled lesson time. }\end{array}$ & & & & \\
\hline $\begin{array}{l}\text { I am tolerant when parents } \\
\text { disagree with me over } \\
\text { matters relating to violin } \\
\text { study. }\end{array}$ & & & & \\
\hline $\begin{array}{l}\text { I am interested in knowing } \\
\text { why parents want their } \\
\text { child to learn the violin. }\end{array}$ & & & & \\
\hline $\begin{array}{l}\text { I welcome the views of } \\
\text { parents on matters relating } \\
\text { to violin study. }\end{array}$ & & & & \\
\hline $\begin{array}{l}\text { I don't like explaining } \\
\text { musical concepts again, to } \\
\text { the same pupil. }\end{array}$ & & & & \\
\hline $\begin{array}{l}\text { I never know if parents } \\
\text { understand my directions. }\end{array}$ & & & & \\
\hline
\end{tabular}

Table 6: Responsiveness components

* Component loadings less than $\mathbf{. 3 6 4}$ for a sample size greater than 200 are suppressed (Stevens, 1992) 


\begin{tabular}{|c|c|c|c|}
\hline & Mean & $\begin{array}{l}\text { Standard } \\
\text { deviation }\end{array}$ & Skewness \\
\hline \multicolumn{4}{|l|}{$\begin{array}{l}\text { Teacher-pupil involvement } \\
\text { (mean inter-item correlation }=.0 .35 \text { ) }\end{array}$} \\
\hline $\begin{array}{l}\text { It is my responsibility to provide information regarding } \\
\text { instruments and materials, to my pupils. }\end{array}$ & 4.46 & .60 & -.63 \\
\hline $\begin{array}{l}\text { Part of my job is to provide performance opportunities } \\
\text { for my pupils }\end{array}$ & 4.37 & .76 & -.10 \\
\hline $\begin{array}{l}\text { It is my responsibility to provide information regarding } \\
\text { appropriate holiday music courses, for my pupils. }\end{array}$ & 3.95 & .84 & -.42 \\
\hline $\begin{array}{l}\text { It is important that I provide information regarding } \\
\text { professional concerts to my pupils. }\end{array}$ & 3.90 & .81 & -.42 \\
\hline $\begin{array}{l}\text { I initiate communication with pupils, outside of scheduled } \\
\text { lesson time. }\end{array}$ & 3.75 & .91 & -.38 \\
\hline \multicolumn{4}{|l|}{$\begin{array}{l}\text { Teacher-parent involvement } \\
\text { (mean inter-item correlation }=0.22 \text { ) }\end{array}$} \\
\hline $\begin{array}{l}\text { I expect parents to attend concerts when their children } \\
\text { are playing the violin. }\end{array}$ & 4.44 & .71 & -1.13 \\
\hline I welcome parents to sit in on lessons. & 4.13 & 1.06 & -1.19 \\
\hline $\begin{array}{l}\text { I am happy to initiate communication with parents, } \\
\text { outside of scheduled lesson time. }\end{array}$ & 4.11 & .76 & -.88 \\
\hline $\begin{array}{l}\text { I welcome communication from parents, outside of } \\
\text { scheduled lesson time. }\end{array}$ & 4.10 & .77 & -.88 \\
\hline I expect parents to assist with practice. & 3.82 & .93 & -.47 \\
\hline I am a better teacher when parents are not there. ${ }^{*}$ & 2.56 & 1.16 & .42 \\
\hline $\begin{array}{l}\text { I do not believe parents should make their children } \\
\text { practice.* }\end{array}$ & 2.24 & 1.03 & .72 \\
\hline
\end{tabular}

Table 7: Outcomes for teachers - involvement

*Scores for these items were reversed when calculating overall scores for the scale 


\begin{tabular}{|c|c|c|c|}
\hline Predictor & $\begin{array}{c}\text { Standardized coefficients } \\
\text { Beta }\end{array}$ & $\mathbf{t}$ & Sig. \\
\hline Sensitivity to pupils (responsiveness 1) & .601 & 6.366 & .001 \\
\hline Commitment (control 2) & .254 & 3.158 & .002 \\
\hline Impatience (control 3) & .206 & 2.194 & .031 \\
\hline Teacher leadership (control 1) & .171 & 1.924 & .057 \\
\hline Confidence (control 4) & -.069 & -.807 & .422 \\
\hline Communication skills (responsiveness 4) & -.069 & -.854 & .395 \\
\hline Receptiveness to new ideas (responsiveness 2) & -.059 & -.627 & .532 \\
\hline Interest in views of others (responsiveness 3) & .025 & .288 & .774 \\
\hline
\end{tabular}

Table 8: Standardized coefficients for control and responsiveness components as predictors of teacher involvement

\begin{tabular}{|l|c|c|c|}
\hline $\begin{array}{l}\text { Teacher efficacy } \\
\text { (mean inter-item correlation = 0.48) }\end{array}$ & Mean & Standard & Skewness \\
violin study, amongst my pupils. & 4.53 & .55 & -.61 \\
\hline I believe I am an effective teacher for my pupils. & 4.43 & .58 & -.41 \\
\hline $\begin{array}{l}\text { I provide my pupils with a strong sense of direction, } \\
\text { on the violin. }\end{array}$ & 4.27 & .72 & -.64 \\
\hline I always explain my expectations clearly to my pupils. & 4.09 & & \\
\hline Teacher professional satisfaction & & & \\
\hline (mean inter-item correlation = 0.75) & & & \\
\hline Teaching the violin is a rewarding job. & 4.66 & & -.44 \\
\hline I am enthusiastic about teaching the violin. & & & \\
\hline
\end{tabular}

Table 9: Outcomes for teachers - teacher efficacy and professional satisfaction 


\begin{tabular}{|l|c|c|c|}
\hline \multicolumn{1}{|c|}{ Predictor } & $\begin{array}{c}\text { Standardized } \\
\text { coefficients } \\
\text { Beta }\end{array}$ & t & Sig. \\
\hline Confidence (control 4) & -.347 & -4.193 & .001 \\
\hline Teacher leadership (control 1) & .324 & 3.777 & .001 \\
\hline Commitment (control 2) & .297 & 3.811 & .001 \\
\hline Sensitivity to pupils (responsiveness 1) & .184 & 2.030 & .045 \\
\hline Impatience (control 3) & -.175 & -1.935 & .056 \\
\hline Receptiveness to new ideas (responsiveness 2) & -.093 & -1.039 & .301 \\
\hline Communication skills (responsiveness 4) & .048 & .617 & .539 \\
\hline Interest in views of others (responsiveness 3) & .012 & .139 & .890 \\
\hline
\end{tabular}

Table 10: Standardized coefficients for control and responsiveness components as predictors of teacher efficacy

\begin{tabular}{|l|c|c|c|}
\hline \multicolumn{1}{|c|}{ Predictor } & $\begin{array}{c}\text { Standardized } \\
\text { coefficients } \\
\text { Beta }\end{array}$ & t & Sig. \\
\hline Sensitivity to pupils (responsiveness 1) & .398 & 4.239 & .001 \\
\hline Interest in views of others (responsiveness 3) & -.292 & -3.402 & .001 \\
\hline Teacher leadership (control 1) & .261 & 2.938 & .004 \\
\hline Confidence (control 4) & -.247 & -2.884 & .005 \\
\hline Impatience (control 3) & .147 & 1.567 & .120 \\
\hline Commitment (control 2) & .077 & .957 & .341 \\
\hline Receptiveness to new ideas (responsiveness 2) & .052 & .560 & .577 \\
\hline Communication skills (responsiveness 4) & .002 & .028 & .978 \\
\hline
\end{tabular}

Table 11: Standardized coefficients for control and responsiveness components as predictors of teacher professional satisfaction 